\title{
DESAIN AUTOMATIC CONTROL SYSTEM POMPA AIR TAWAR PADA KAPAL RAKYAT
}

\author{
Franky Tanahitumessing ${ }^{1, *}$ \\ ${ }^{1}$ Lab. Mekanika Fluida dan Mesin Fluida Fakultas Teknik Universitas Pattimura, Ambon 97233 \\ *e-mail: aldi01dell@gmail.com
}

\begin{abstract}
Abstrak. Persediaan air tawar pada kapal rakyat merupakan kebutuhan vital yang harus dipenuhi selama kapal melakukan pelayaran. System penyaluran air tawar yang digunakan tanpa pengontrolan akan merepotkan Anak Buah Kapal (ABK), yang selalu bertugas untuk mengontrol ketersediaan air pada tangki harian dan menjalankan pompa air. Alat kontrol pompa air dipakai untuk membantu mengurangi waktu kerja ABK dan dapat meningkatkan efisiensi kinerja pompa air. Saklar pelampung merupakan alat kontrol yang sering dipakai, namun sistem pelampungnya akan terganggu seiring waktu pemakaian. Automatic control system dengan menggunakan sensor level air belum familiar digunakan untuk mengontrol pompa air. Dari hasil desain yang dilakukan sistem ini lebih efisien dibanding saklar pelampung. Efisiensinya dapat dilihat dari tingkat kepekaan terhadap perubahan tinggi permukaan air, dan juga umur pakai yang lebih lama. Sistem ini dapat digunakan untuk mengontrol kerja pompa air tanpa pengawasan atau pengontrolan dari Anak Buah Kapal (ABK), sehingga lebih menghemat waktu dan ketersediaan air pada tangki harian tetap tersedia setiap saat.
\end{abstract}

Kata kunci : kontrol pompa air, automatic control system, sensor level air.

\begin{abstract}
Freshwater supplies on people's ships are a vital need that must be met during the ship's voyage. The distribution system used without control will be troublesome for the Crew, who are always in charge of controlling the availability of water in the daily tank and running the water pump. Water pump control equipment is used to help reduce the working time of the Crew and can improve the performance efficiency of the water pump. A buoy switch is a control tool that is often used, but the buoy system will be disrupted over time. An automatic control system using a water level sensor is not familiar to use to control the water pump. From the design results of this system is more efficient than the buoy switch. Its efficiency can be seen from the degree of sensitivity to changes in water level, as well as longer service life. This system can be used to control the work of water pumps without supervision or control of the Crew, thus saving more time and the availability of water in the daily tank remains available at all times.
\end{abstract}

Keywords: water pump control, automatic control system, water level sensor.

\section{PENDAHULUAN}

Pelayaran rakyat juga telah berfungsi sebagai penggerak roda perekonomian masyarakat di wilayah-wilayah pedalaman yang terpencil dan pulau-pulau terluar untuk mendistribusikan barang hasil bumi dan jasa, maupun untuk mendistribusikan barang-barang kebutuhan pokok yang diperlukan masyarakat. Peran pelayaran rakyat ini tidak tergantikan oleh kapal-kapal bertonase besar mengingat kedalaman perairan pantai dan sungai yang semakin dangkal akibat proses sedimentasi yang tidak dapat dikendalikan [1].

Ketersediaan air bersih (air tawar) pada saat pengoperasian kapal rakyat merupakan salah satu kebutuhan vital. Untuk itu, sistem penyediaan air bersih harus didesain sedemikian rupa dapat digunakan setiapsaat.Fungsi air tawar adalah sebagai air minum, cuci, mandi, dan lain-lain [2]. Air minum untuk para awak dan penumpang kapal disimpan di dalam storage tank. Dari storage tank, air minum tersebut akan dialirkan menuju service tank yang kemudian dari service tank akan 
dialirkan menuju ruangan-ruangan yang membutuhkan [3].

Dan untuk mempertahankan kelancaran sistem penyediaan air tawar (air bersih), maka pompa air merupakan bagian vital dari suatu instalasi pipa air bersih, yakni dengan satu tujuan mampu memperlancar aliran air sampai ke tujuan. Namun dalam penggunaannya sering tidak terkontrol dengan baik sehingga terjadi pemborosan atau dapat dikatakan bahwa penggunaannya belum efektif, bahkan dapat mengakibatkan kerusakan pada pompa akibat umur pakai yang tidak terkontrol, karena kesibukan Anak Buah Kapal yang melakukan aktivitas lain di kapal. Setiap manusia pasti memiliki kesalahan dan kelalaian dalam mengingat atau melakukan sesuatu (human error) [4]. Untuk itu, diperlukan alat bantu untuk mengontrol kinerja pompa air sehingga penggunaannya menjadi lebih efektif dan tidak terjadi pemborosan atau luapan air yang terbuang percuma, juga dapat memperpanjang umur pakai dari mesin pompa tersebut. Contoh yang paling sederhana saja ialah pengaturan mati dan hidup pompa pengisian tangki air yang menggunakan Level Control [5].

Alat kontrol yang sangat familiar yakni saklar pelampung, yang menggunakan sebuah sistem mekanis sederhana dengan sebuah saklar (limit switch) dengan tali untuk mengikat pelampung. Saklar pelampung ini mempunyai keuntungan yakni sederhana dan mudah dalam pemasangan serta pengoperasiannya.

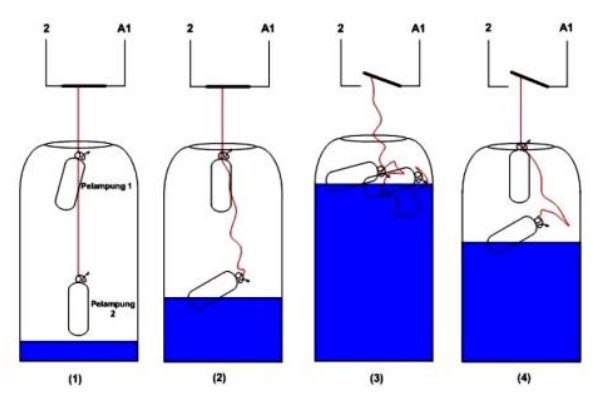

Gambar 1. Cara kerja saklar pelampung.

Namun ada pula kerugiannya yakni sistem kerja saklar akan terganggu karena lapuknya tali yang digunakan akibat terendam air.

Hal inilah yang menjadi motivasi bagi penulis untuk mendesain sebuah automatic control system dengan menggunakan sensor level air (water level sensor). Sistem ini menggunakan tigabuah elektroda celup yang berfungsi sebagai common power, low level dan high level dari level ketinggian air. Pada sistem ini, tidak menggunakan saklar mekanik seperti pada saklar pelampung, namun dengan sistem ini, air akan berfungsi seperti saklar untuk menghubungkan aliran listrik ke relay yang digunakan.

Desain automatic control system ini bertujuan untuk menggantikan sistem saklar pelampung dalam mengontrol kinerja pompa air sehingga lebih efisien dan efektif, dan dapat menghemat waktu kerja anak buah kapal (crew) di kapal.

\section{BAHAN DAN METODE}

Untuk mendesain automatic system ini diperlukan beberapa bahan pokok yang menjadi sarana utama, yakni relay magnetik (magnetic relay) dan adaptor sebagai power suplay yang mengubah arus listrik ac menjadi dc.

\subsection{Magnetic Relay}

Magnetic Relay merupakan komponen listrik yang prinsip kerjanya sama dengan saklar, yakni menghubungkan dan atau memutuskan aliran listrik ke beban listrik. Relay bekerja dengan menggunakan arus listrik yang terhubung ke kumparannya, yang kemudian menimbulkan gaya magnet untuk menarik saklar internal yang ada pada relay tersebut. Saklar internal inilah yang disebut sebagai kontak NO (Normally Open= Bila coil contactor atau relay dalam keadaan tak terhubung arus listrik, kontak internalnya dalam kondisi terbuka atau tak terhubung) dan kontak NC (Normally Close $=$ Sebaliknya dengan Normally Open) [6].

Ada bermacam-macam relay yang digunakan dalam dunia kelistrikan maupun elektronik. Misalnya dalam dunia kelistrikan ada yang dikenal dengan nama kontaktor, yakni tipe relay daya yang cukup besar, yang digunakan untuk mengontrol mesin-mesin listrik dengan daya besar. Ada juga tipe relay yang digunakan dalam dunia elektronika, yang berukuran kecil dengan daya yang kecil pula.

Dalam desain ini, digunakan relay type Omron $12 \mathrm{VDC}$ coil $250 \mathrm{VAC}$ contact 8 pin.

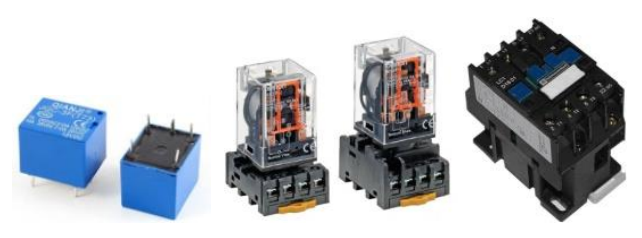

Gambar 4. Contoh Tipe Relay

\subsection{Adaptor (Power Suplay DC)}

Adaptor merupakan rangkaian penyearah yang mengubah tegangan bolak-balik (ac) menjadi tegangan searah (dc). Rangkaian ini merupakan rangkaian elektronika sederhana yang terdiri dari transformator dan dioda sebagai komponen utama. 
Ada 3 (tiga) jenis rangkaian penyearah yang dikenal dalam dunia eletrik maupun elektronik [7].

a. Penyearah Setengah Gelombang, seperti pada gambar. Penyearah jenis ini jarang digunakan.

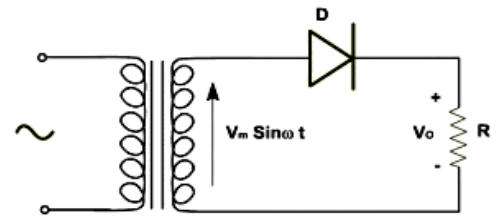

Gambar 5. Penyearah setengah gelombang

b. Penyearah Gelombang Penuh, seperti pada gambar. Penyearah jenis ini menggunakan 2 (dua) buah dioda dengan transformator yang titik nol berada di tengah.

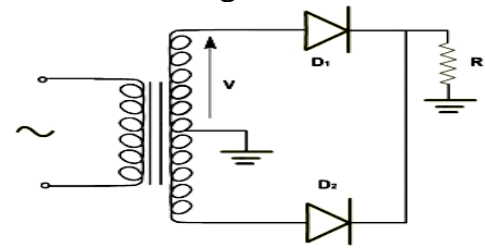

Gambar 6. Penyearah Gelombang Penuh

c. Penyearah Gelombang Penuh Tipe Jembatan (Bridge) seperti terlihat pada gambar. Jenis penyearah ini menggunakan empat buah dioda.

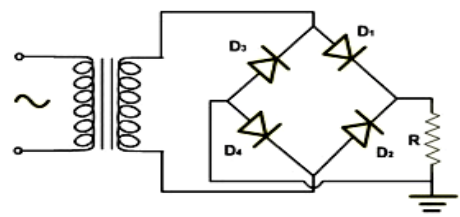

Gambar 7. Penyearah Gelombang Penuh Tipe Jembatan.

Untuk memperbaiki atau menghaluskan output dari rangkaian penyearah, maka dapat digunakan kapasitor elektrolit yang dihubungkan pada output penyearah tersebut.

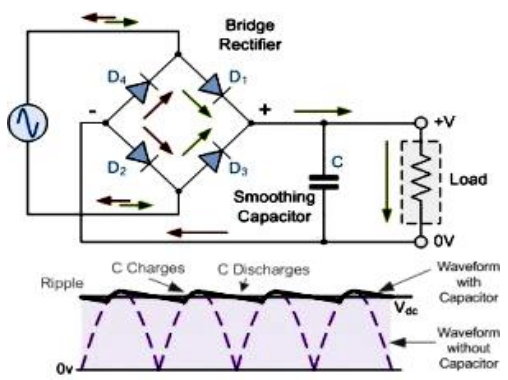

Gambar 8. Kapasitor sebagai penghalus gelombang

Berikut contoh DC power suplay (adaptor) yang dilengkapi dengan IC Regulator [8].

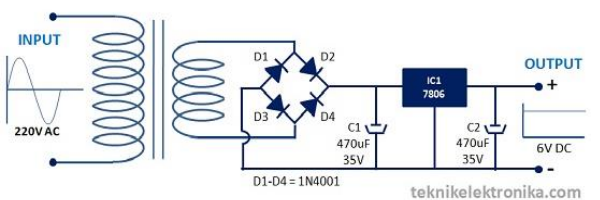

Gambar 9. Rangkaian DC Power Suplay.

\subsection{Motor Listrik (Motor Induksi)}

Motor induksi merupakan motor listrik yang paling banyak digunakan dalam kehidupan masyarakat. Motor ini mempunyai konstruksi yang sederhana, kuat dan mudah dioperasikan [9]. Disebut motor induksi karena arus rotor motor ini bukan diperoleh dari sumber tertentu tetapi merupakan arus yang terinduksi akibat adanya perbedaan relatif antara putaran rotor dengan medan putar yang dihasilkan oleh arus stator [10]. Perbedaan putaran relatif antara stator dan rotor disebut slip [11]. Bertambahnya beban akan memperbesar kopel motor, yang oleh karenanya akan memperbesar pula arus induksi pada rotor, sehingga slip antara medan putar stator dan putaran rotor akan bertambah besar.

Untuk mengimbangi beban yang besar, maka pada motor induksi dapat dipasang pula kumparan bantu pada stator yang dilengkapi dengan kapasitor dan sebuah saklar yang bekerja akibat adanya gaya sentrifugal pada rotor. Dengan dipasangnya kapasitor pada kumparan bantu, maka akan timbul beda fasa $90^{\circ}$ antara arus pada kumparan utama dan arus kumparan bantu dan karenanya diperoleh kopel mula yang lebih besar. Menurut hubungan kapasitor, terdapat 3 (tiga) tipe motor kapasitor, yaitu :

1) Motor kapasitor start (starting capacitor motor)

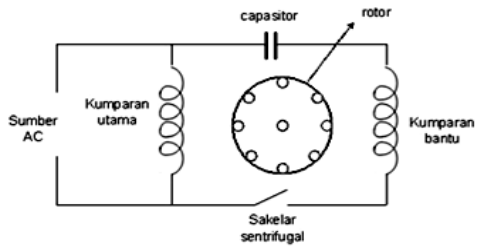

Gambar 10. Skema Motor Kapasitor Start

2) Motor kapasitor tetap/running (permanent capacitor motor)

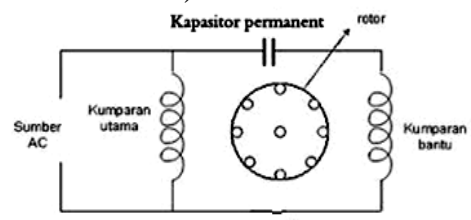

Gambar 11. Skema Motor Kapasitor Tetap / Running

3) Motor kapasitor start-running (startrunning capacitor motor) 


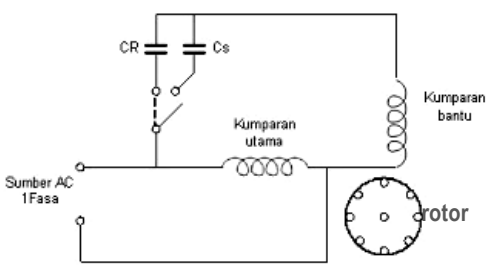

Gambar 12. Skema Motor Kapasitor StartRunning

Motor kapasitor merupakan salah satu jenis motor induksi yang menggunakan kapasitor dalam konstruksinya [10].

Motor listrik jenis kapasitor banyak dipakai untuk keperluan rumah seperti kompresor, pompa air, mesin pendingin, yang memang memerlukan kopel mula yang cukup besar [12].

Dengan demikian, dapat kita ketahui bahwa sebenarnya, mesin pompa air merupakan salah satu jenis motor listrik dengan tipe motor kapasitor.

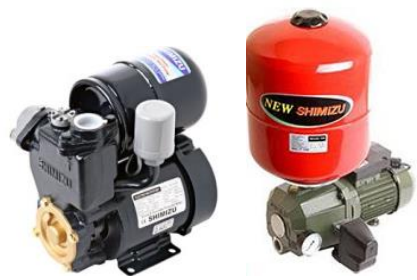

Gambar 13. Contoh Mesin Pompa Air

\subsection{Metode dan Bahan Yang Digunakan}

Desain automatic control system ini menggunakan metode sistem kontrol lup tertutup. Sistem kontrol lup tertutup merupakan sistem kontrol yang sinyal keluarannya mempunyai pengaruh langsung pada aksi pengontrolan. Sistem ini adalah sistem kontrol berumpan balik. Sinyal kesalahan penggerak, yang merupakan selisih antara sinyal masukan dan sinyal umpan balik (yang dapat berupa sinyal keluaran atau suatu fungsi sinyal keluaran dan turunannya), diumpankan ke kontroler untuk memperkecil kesalahan dan membuat agar keluaran sistem mendekati nilai yang diinginkan [13].

Desain ini menggunakan rangkaian sederhana yang terdiri dari 3 (tiga) buah relay DC dan 3 buah sensor level air serta 1 buah adaptor AC-DC.

Automatic control system ini merupakan rangkaian sangat sederhana sehingga dapat digunakan sesuai kebutuhan penggunaan pompa. Jika pompa yang berkapasitas kecil, dapat digunakan relay kapasitas kecil, sebaliknya jika pompa kapasitas besar, digunakan relay kapasitas besar, atau bahkan dapat menggunakan jenis kontaktor daya.
Selain bahan-bahan pokok diatas, terdapat pula beberapa bahan lain yang perlu dipersiapkan antara lain :

- 2 buah lampu indikator (hijau dan merah)

- 3 buah baut stainless steel

- 2 meter pipa PVC $1 / 2$ "

- 2 buah sambungan cabang pipa PVC $1 / 2$ "

- 2 buah sambungan belokan $90^{\circ}$ pipa PVC $1 / 2$ "

- 4 buah dop pipa PVC 1/2"

- Kabel NYYHY 3x0,75 mm² secukupnya.

- 1 buah box, ukuran $20 \mathrm{~cm}$ x $20 \mathrm{~cm}$ x $15 \mathrm{~cm}$

\section{HASIL DAN PEMBAHASAN}

\subsection{Cara Kerja Alat Kontrol Pompa Air}

Cara kerja alat kontrol pompa air dengan rangkaian relay dan elektroda celup sebagai sensor level air, dapat dijelaskan berdasarkan Gambar 14.

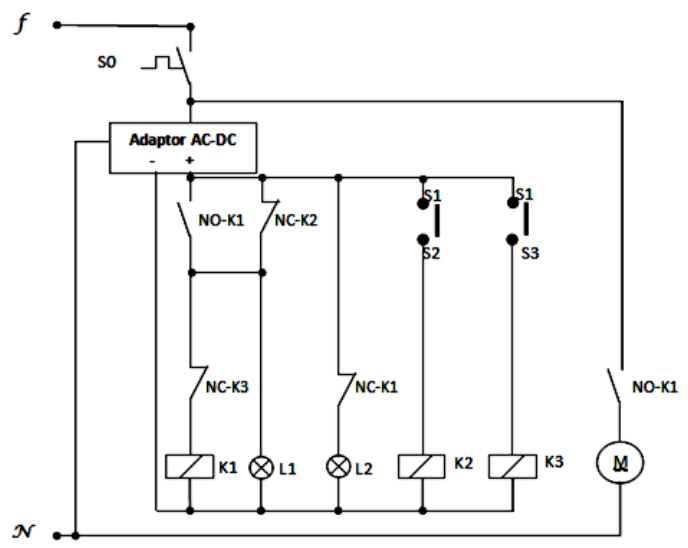

Gambar 14. Skematik diagram alat kontrol

\section{Keterangan Gambar :}

$f$ dan $N=$ Kabel Sumber Listrik AC

S0 $=$ MCB

$\mathrm{S} 1$ = Sensor yang terendam

S2 = Sensor level bawah

S3 = Sensor level atas

| =Permukaan air dalam tangki

$\mathrm{K} 1=$ Relay $1 ; \mathrm{K} 2=$ Relay $2 ; \mathrm{K} 3=$ Relay 3

NO-K1 = Kontak NO Relay 1

NC-K2 $=$ Kontak NC Relay 2

NC-K3 = Kontak NC Relay 3

$\mathrm{L} 1=\mathrm{L} 2=$ lampu indikator

$\mathrm{M}=$ Mesin Pompa Air

Bila kita mencermati gambar 14 di atas, maka kondisi seperti ini adalah kondisi dimana tangki air dalam keadaan kosong (sensor terbuka), maka cara kerja rangkaian kontrol adalah sebagai berikut :

1) Ketika kabel listrik dihubungkan ke sumber listrik dan MCB S0 di-ON-kan maka arus listrik akan mengalir melalui Adaptor AC-DC dan diteruskan ke relay $\mathrm{K} 1$ melalui kontak NC-K2 dan NC-K3. Saat relay K1 bekerja maka kontak NO-K1 mengunci dan 
mengalirkan arus ke motor pompa sehingga pompa bekerja untuk memompa air ke tangki penampung. Pada saat yang bersamaan kontak NO-K1 yang terhubung dengan kontak NC-K2 mengunci sehingga jika air mulai terisi dan sensor S1 terhubung dengan sensor S2 yang mengakibatkan relay $\mathrm{K} 2$ bekerja, maka relay $\mathrm{K} 1$ tetap bekerja karena arus mengalir melalui kontak NO-K1 yang telah mengunci dan lampu tanda L1 menyala. Kondisi kerja I ini ditunjukkan pada Gambar 15.

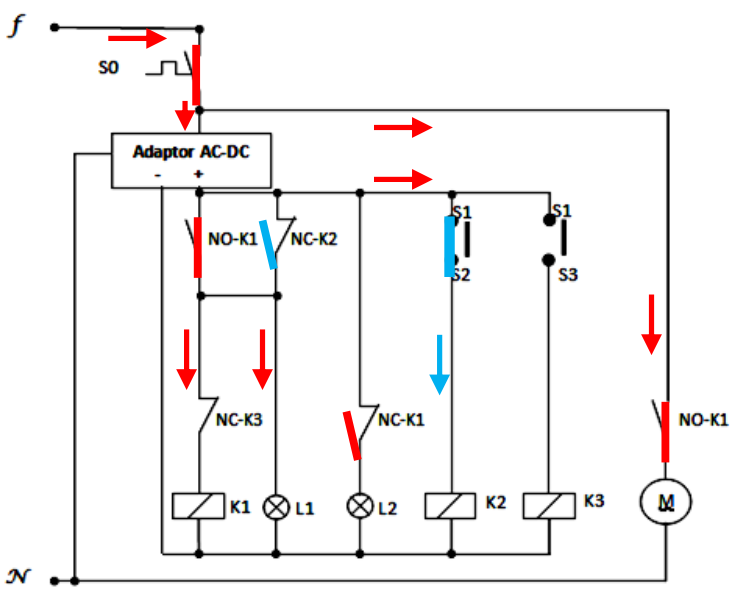

Gambar 15. Kondisi kerja I.

2) Ketika air dalam tangki naik sampai pada level atas dan sensor S3 terhubung dengan S1, maka relay $\mathrm{K} 3$ bekerja dan memutuskan aliran arus ke relay $\mathrm{K} 1$ melalui kontak $\mathrm{NC}-\mathrm{K} 3$, sehingga kontak NO-K1 yang menghubungkan arus ke pompa terbuka dan arus terputus yang mengakibatkan pompa berhenti bekerja. Pada saat yang bersamaan, lampu tanda L2 akan menyala karena mendapat aliran melalui kontak NC-K1. Kondisi kerja II ini, ditunjukkan pada Gambar 16.

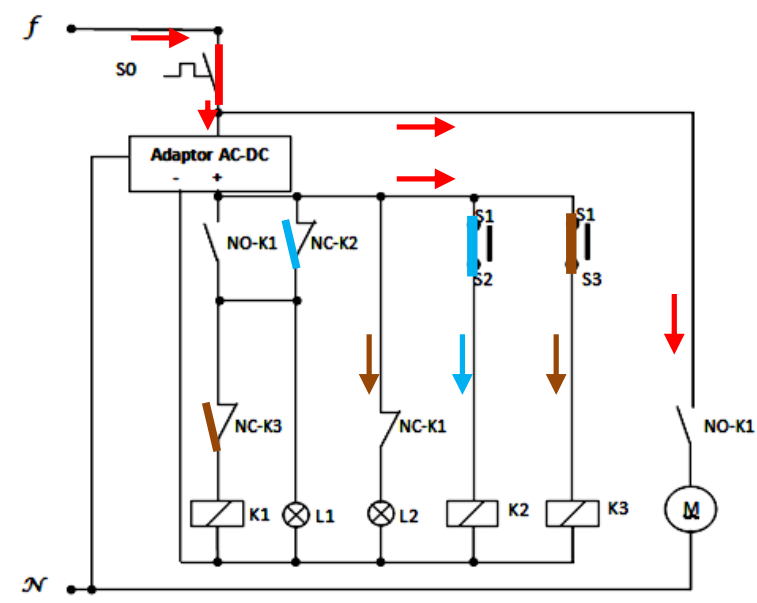

Gambar 16. Kondisi kerja II.

3) Ketika air dalam tangki mulai turun,sensor $\mathrm{S} 3$ dan S1 terputus, mengakibatkan relay K3 terputus dan tidak bekerja sehingga kontak NC-K3 kembali terhubung. Dan saat air sampai pada level bawah dan hubungan antara sensor S2 dan S1 terputus, maka kontak NCK2 kembali terhubung sehingga arus mengalir dan mengakibatkan relay K1 bekerja dan lampu tanda L1 kembali menyala. Dengan demikian pompa akan kembali bekerja secara otomatis (Gambar 17).

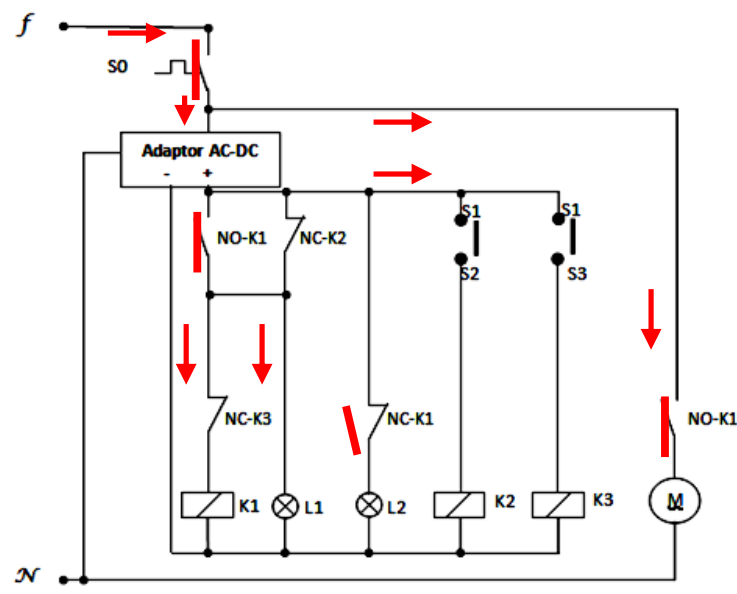

Gambar 17. Kondisi kerja III.

Secara singkat kondisi kerja rangkaian kontrol ini, dapat dilihat pada tabel 1 .

Tabel 1. Kondisi kerja rangkaian

\begin{tabular}{|c|c|c|c|c|c|c|c|c|c|}
\hline So & $\begin{array}{l}\text { S1- } \\
\text { S2 }\end{array}$ & $\begin{array}{l}\text { S1- } \\
\text { S3 }\end{array}$ & K1 & K2 & K3 & L1 & L2 & $\mathbf{M}$ & $\begin{array}{c}\text { Kondisi Kerja } \\
\text { Rangkaian }\end{array}$ \\
\hline OFF & 0 & 0 & 0 & 0 & 0 & 0 & 0 & 0 & $\begin{array}{l}\text { Semua kontak terbuka. } \\
\text { Rangkaian dalam kondisi } \\
\text { tidak bekerja. }\end{array}$ \\
\hline ON & 1 & 0 & 1 & 1 & 0 & 1 & 0 & 1 & $\begin{array}{l}\text { NO-K1 terhubung; } \\
\text { NC-K2 terbuka; } \\
\text { NC-K1 terbuka. } \\
\text { Pompa bekerja dan air } \\
\text { masuk ke dalam tangki. }\end{array}$ \\
\hline ON & 1 & 1 & 0 & 1 & 1 & 0 & 1 & 0 & $\begin{array}{c}\text { NC-K3 terbuka; } \\
\text { NO-K1 terbuka; } \\
\text { NC-K1 terhubung. } \\
\text { Air penuh dan pompa } \\
\text { berhenti. }\end{array}$ \\
\hline ON & 0 & 0 & 1 & 0 & 0 & 1 & 0 & 1 & $\begin{array}{l}\text { NC-K2 terhubung; } \\
\text { NO-K1 terhubung; } \\
\text { NC-K3 terhubung. } \\
\text { NC-K1 terbuka. } \\
\text { Air mencapai level bawah } \\
\text { dan pompa kembali } \\
\text { bekerja. }\end{array}$ \\
\hline ON & 1 & 0 & 1 & 1 & 0 & 1 & 0 & 1 & $\begin{array}{l}\text { NO-K1 terhubung; } \\
\text { NC-K2 terbuka; } \\
\text { NC-K1 terbuka. } \\
\text { Pompa bekerja dan air } \\
\text { masuk ke dalam tangki. }\end{array}$ \\
\hline ON & 1 & 1 & 0 & 1 & 1 & 0 & 1 & 0 & $\begin{array}{l}\text { NC-K3 terbuka; } \\
\text { NO-K1 terbuka; } \\
\text { NC-K1 terhubung. } \\
\text { Air penuh dan pompa } \\
\text { berhenti. }\end{array}$ \\
\hline OFF & 0 & 0 & 0 & 0 & 0 & 0 & 0 & 0 & $\begin{array}{c}\text { Semua kontak terbuka. } \\
\text { Rangkaian dalam kondisi } \\
\text { tidak bekerja. }\end{array}$ \\
\hline
\end{tabular}

Demikian kondisi kerja ini akan berulang selama MCB S0 masih dalam keadaan ON, dan 
bila MCB S0 di-OFF-kan maka seluruh rangkaian terputus.

\subsection{Tata Letak Alat Kontrol dan Sensor.}

Tata letak peralatan kontrol didesain agar dapat diletakkan dekat pompa. Itu berarti peralatan kontrol ini akan berada di ruang mesin dimana pompa air tawar diletakkan.

Dalam hal ini, sistem perpipaan tidak ada pengaruhnya dengan tata letak, karena yang didesain hanyalah peralatan kontrol automatic systemnya saja.

Sementara letak sensor level air tetap berada dalam tangki dengan posisi sebagai berikut :

- Sensor 1 , terletak di dasar tangki dan selalu terendam air, sebagai common sensor.

- Sensor 2, terletak di bagian bawah tangki lebih kurang $10 \mathrm{~cm}$ dari Sensor 1, dan berfungsi sebagai sensor level bawah (bottom level sensor).

- Sensor 3, terletak di bagian atas tangki, lebih kurang $10 \mathrm{~cm}$ dari penutup tangki, dan berfungsi sebagai sensor level atas (top level sensor).

Posisi sensor ini akan didesain menggunakan baut yang dipasang pada pipa paralon (PVC) 1/2", sehingga yang terkena air hanyalah bautnya saja. Tata letak peralatan dan posisi sensor dalam tangki ditunjukkan pada Gambar 18.

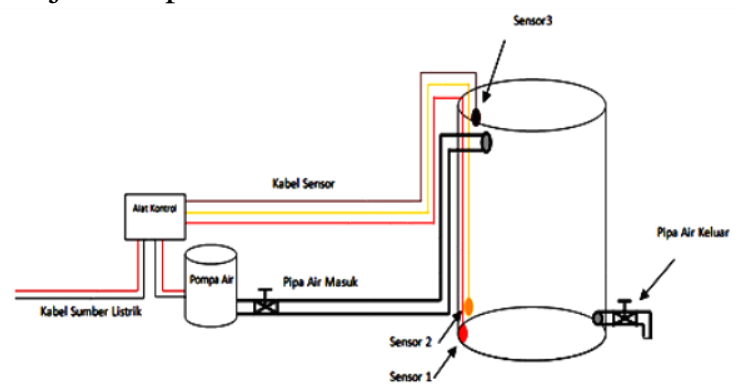

Gambar 18. Tata Letak Sensor Dalam Tangki

\subsection{Desain Rangkaian Alat Kontrol dan Pemasangan Sensor Level Air.}

Berdasarkan gambar skematik (gambar 14), maka alat kontrol pompa air sebagai bagian utama dari automatic control system ini, maka rangkaian alat kontrol ini didesain dengan urutan perakitan sebagai berikut :

1) Siapkan box kayu, untuk meletakkan seluruh material sistem kontrol, kecuali sensor yang nantinya akan diletakkan dalam tangki.

2) Siapkan rangkaian adaptor, sebagai power suplay pada rangkaian kontrol dan diletakkan dalam box dengan bagian aliran masuk AC terhubung ke terminal strip yang telah dipasang pada bagian tepi box (bagian input).
3) Siapkan ketiga relay, yang berfungsi sebagai saklar magnetik untuk menghubungkan dan memutuskan aliran ke pompa. Relay diletakkan dalam box, dengan kabel sensor dan kabel pompa, terhubung ke terminal strip (bagian output).

4) Hubungkan rangkaian adaptor ke relay dan lampu indikator sesuai gambar skematik diagram (gambar 14). Kabel yang akan dihubungkan dengan sumber listrik dan pompa, dihubungkan ke terminal strip.

5) Rangkaian kontrol siap digunakan.

Demikian pula pemasangan sensor level air didesain sesuai dengan tata letak pada gambar 18. Pemasangan sensor ini dapat dilakukan dengan urutan sebagai berikut :

1) Siapkan pipa paralon (PVC) $1 / 2 "$ dengan panjang sesuai tinggi tangki. Kemudian potong pipa untuk penempatan sensor bawah dan sensor atas, yang disambung dengan menggunakan sambungan cabang $\mathrm{T}$.

2) Masukkan kabel sensor (kabel NYMHY $3 \mathrm{x}$ $0,75 \mathrm{~mm}^{2}$ ) dengan ujung kabel pertama untuk common sensor yang terletak di ujung bawah pipa (terletak pada dasar tangki); ujung kabel kedua untuk bottom level (kira-kira $10 \mathrm{~cm}$ dari common sensor); dan ujung kabel ketiga untuk top level (kira-kira $10 \mathrm{~cm}$ dari penutup tangki).

3) Pasangkan dop yang telah dipasang mur baut pada ujung pipa bagian bawah untuk common sensor. Sedangkan untuk sensor bawah dan sensor atas, dop dipasang pada ujung sambungan cabang $\mathrm{T}$ yang telah diberi sepotong pipa.

4) Pada ujung pipa bagian atas, yang keluar melalui lubang penutup tangki, dipasang sambungan belokan $90^{\circ}$, sehingga kabel tetap terlindungi.

5) Kabel sensor dari tangki dihubungkan ke terminal strip pada box kontrol, sesuai urutan pada gambar skematik diagram (gambar 14).

6) Seluruh sistem siap untuk digunakan.

\subsection{Desain Automatic Control System Pompa Air Tawar Pada Kapal Rakyat}

Automatic control system pompa air tawar pada kapal kayu (kapal rakyat) didesain sedemikian rupa sehingga tidak tergantung pada system perpipaan yang ada. Dalam hal ini, hanya terfokus pada peralatan kontrol yang didesain sebagai automatic control system pompa air tawar pada kapal.

Sesuai dengan cara kerja dan gambaran letak peralatan kontrol, serta posisi sensor dalam tangki, maka letak box kontrol (tempat peralatan kontrol) 
dan pompa air tawar dapat diasumsikan seperti pada gambar berikut.

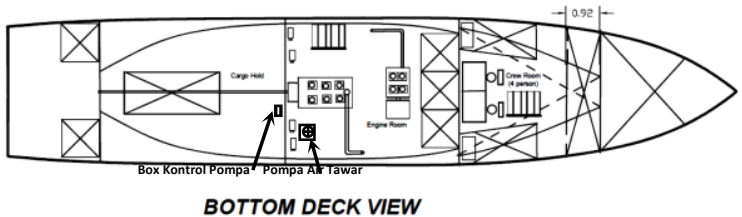

Gambar 19. Letak Pompa Air Tawar dan Box Kontrol Pompa

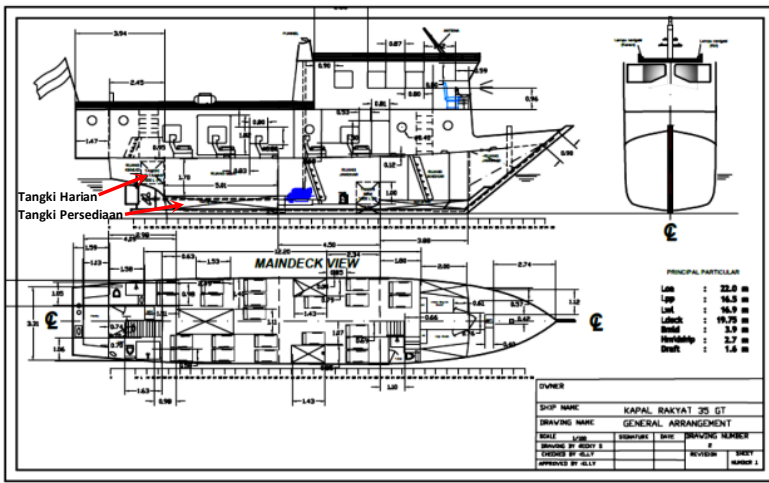

Gambar 20. Letak Tangki Persediaan dan Tangki Harian.

Dari gambar 19, dapat dilihat bahwa box panel peralatan kontrol diletakkan dalam ruang mesin bersamaan dengan pompa, sehingga kabel yang menghubungkan box panel kontrol dengan pompa tidak terlalu jauh. Namun, oleh karena letak tangki harian berada dibagian belakang kapal, maka kabel sensor yang dibutuhkan lumayan panjang, sesuai jarak antara box panel kontrol dengan tangki harian (gambar 20).

Hasil dari desain automatic control system ini adalah sebagai berikut :

1) Dengan memperhatikan jarak ruang mesin dengan tangki harian yang harus dikontrol setiap saat, maka automatic control ini dapat menghemat waktu dan tenaga dari crew (ABK).

2) Penempatan box panel peralatan kontrol yang berdekatan dengan pompa memungkinkan dilakukannya perawatan yang lebih mudah.

3) Waktu operasi pompa menjadi lebih hemat sehingga dapat memperpanjang umur pakai.

4) Efisiensi penggunaan air bersih di kapal semakin baik.

\section{KESIMPULAN}

Berdasarkan hasil dan pembahasan diatas, dapat disimpulkan bahwa dengan menggunakan desain automatic control system pompa air tawar ini, maka :
1) Dapat lebih meningkatkan efektifitas dan efisiensi kinerja pompa air, dibandingkan dengan kinerja pompa tanpa alat kontrol.

2) Dapat memperpanjang umur pakai dari mesin pompa air, karena waktu istirahat mesin cukup lama.

3) Dapat meringankan pekerjaan petugas, sehingga tidak harus mengontrol setiap kali air penuh.

4) Dapat menghemat air karena tidak ada lagi air yang terbuang percuma saat tanki penampung (tangki harian) penuh.

5) Dapat menghemat pemakaian energi listrik.

6) Desain automatic control system ini masih dapat dikembangkan lagi, jika diperlukan.

\section{DAFTAR PUSTAKA}

[1] R. Indrawasih, "Jurnal Penelitian Transportasi Laut The Marginalized of People Shipping in Central Maluku Districts and," vol. 20, pp. 40-54, 2018.

[2] Y. Rezandy, Desain sistem perpipaan air tawar pada kapal patroli. 2019.

[3] D. Kurniawan and A. Baheramsyah, "Studi kebutuhan air tawar pada pengembangan landing shiptank (LST) 128 meter berdasarkan perilaku manusia," Undergrad. Theses, 2011.

[4] Khair, "Alat Pendeteksi Ketinggian Air Dan Keran Otomatis Menggunakan Water Level Sensor Berbasis Arduino Uno," Wahana Inov. J. Penelit. dan Pengabdi. Masy. UISU, vol. 9, no. 1, pp. 9-15, 2020, [Online].

Available: https://jurnal.uisu.ac.id/index.php/wahana/a rticle/view/2632.

[5] I. Setiadi, "Perancangan Sistem Kontrol Otomatis Air Baku dan Air Produksi Pada Unit Arsinum SMK AL-KAHFI Kabupaten Sumbawa," vol. 10, no. 2, pp. 91-98, 2017.

[6] Suprianto, "Prinsip Kerja Elektro Mekanis Magnetik (Dasar NO \& NC)," UNNES, 2015.

http://blog.unnes.ac.id/antosupri/prinsipkerja-elektro-mekanis-magnetik-dasar-no$\mathrm{nc} /$.

[7] A. Purnama, "Konsep Dasar Penyearah Gelombang (Rectifier)," 2012. http://elektronika-dasar.web.id/konsepdasar-penyearah-gelombang-rectifier/.

[8] D. Kho, "Prinsip Kerja DC Power Suplay," 2014.

https://teknikelektronika.com/prinsip-kerjadc-power-supply-adaptor/.

[9] Z. Anthony and E. Erhaneli, "Desain Lilitan Motor Induksi 1-Fasa dengan 4 
Kumparan yang Tidak Identik Sama (Studi Kasus: Daya Keluaran dan Efisiensi Motor)," Jurnal EECCIS, vol. 12, no. 2, pp. 89-92, 2018.

[10] A. Defarian, S. Sutikno, and R. Rinaldi, "Pemodelan Dan Simulasi Motor Kapasitor Pada Kondisi Variable Speed," J. Online Mhs. Fak. Tek. Univ. Riau, vol. 4, no. 2, pp. 1-15, 2017.

[11] M. Naim, "Pengaruh Modifikasi Belitan Stator Motor Induksi Satu Phasa Starting Kapasitor Pada Mesin Bor Meja Terhadap Arus dan Daya listrik serta Putaran Motor," Vertex Elektro, vol. 12, no. 2, pp. 34-43, 2020, doi: 10.26618/jte.v12i2.4228.

[12] M. Robith, "Prinsip Kerja Motor Induksi 1 Fasa," 2015. http://www.insinyoer.com/prinsip-kerjamotor-induksi-1-fasa/.

[13] I. Mardjun et al., "Rancang Bangun Solar Tracking Berbasis Arduino Uno," Tek. Elektro, vol. 1, no. 2, pp. 19-24, 2018. 